\title{
Bioprospecting Potential of Endophytic Bacteria from Leaves of Gossypium hirsutum
}

\author{
Azba A. Shaikh ${ }^{*}$, P.R. Parmar ${ }^{2}$, B.K. Rajkumar ${ }^{2}$, D.H. Patel $^{2}$, \\ H.R. Desai ${ }^{2}$ and B.G. Solanki ${ }^{2}$ \\ ${ }^{1}$ Shree Ramkrishna Institute of Computer Education and Applied Sciences, \\ M.T.B College Campus, Surat-395 001, Gujarat, India \\ ${ }^{2}$ Main Cotton Research Station (MCRS), NAU, Athwa Farm, GhodDod Road, \\ Surat - 395007, Gujarat, India \\ *Corresponding author
}

A B S T R A C T

A total of 19 bacterial endophytes were isolated from leaves of cotton (Gossypium hirsutum) and characterized for plant growth promoting traits viz., siderophores production, phosphate solubilization, IAA and ammonia production; and preliminarily

Keywords

Gossypium

hirsutum,

Endophytic bacteria, PGPR, Bioprospect.

\section{Article Info}

Accepted:

17 September 2017

Available Online:

10 October 2017 screened for chitinase, gelatinase, protease and lipase. Quantitative analysis of siderophores production and phosphate solubilization indicated that six endophyteseach viz., EB11, EB4, EB3, EB5, EB8 and EB9 were able to produce siderophores ranging between 80.26 to $92.58 \%$ and EB9, EB11, EB14, EB17, EB4 and EB2 solubilized phosphorus ranging $10.24-13.58 \mathrm{mg} / \mathrm{ml}$ within $48 \mathrm{hrs}$. After $72 \mathrm{hrs}$ incubation, seven isolates EB3, EB13, EB8, EB11, EB15, EB2 and EB17 produced IAA in range of 15-28 $\mu \mathrm{g} / \mathrm{ml}$. Within $48 \mathrm{hrs}$, the ammonia production ranged from 0.8 to $1.6(\mu \mathrm{g} / \mathrm{ml})$. Primary screening of enzymes showed that chitinase was produced by EB5 $(1.9 \mathrm{~mm})$ and EB3 $(1.1$ $\mathrm{mm})$; protease by EB15, EB12, EB11, EB1 and EB4 (11.80-16.60mm); gelatinase by EB1, EB9, EB1, EB12 and EB16 (10.00 -17.00mm); and lipase by EB10, EB13, EB17, EB14, EB12 and EB11 (10.00-15.00mm). Results suggested all endophytic bacterial strains studied are potential for the one or other parameter studied thus further study will help to make consortium as biofertilizer or bioprotectant to enhance plant productivity and protection.

\section{Introduction}

Plant growth promoting microbes is an attractive way to replace chemical or synthetic compounds in agriculture field because of its eco-friendly and economical feasibility (Bhattacharyya et al., 2012; Kirti et al., 2016). The 'biopropecting' word describes the collection and screening of biological material for commercial purpose. Every naturally propagated plant is colonized by divert communities of microbes referred to as 'endophytes'. Endophytes defined as microorganisms that can be isolated from surface-disinfected plant tissues or extracted from within plants and that do not harm the host plants (Hallmann et al., 1998). Recent studies have indicated that endophytes play many important beneficial roles in the metabolism and physiology of the host plant 
via direct and indirect way. Direct way includes production of phytohormones, phosphorous solubilisation, nitrogen fixation, and siderophore production as an iron chelators etc., while indirect way includes suppression of plant diseases by elevating plant resistance mechanisms or by producing various enzymes or metabolites (Bakker and Schippers, 1987; DéFago et al., 1990; Kachhap et al., 2014). In last few decades a large array of endophytic bacterial species of Pseudomonas, Azospirillum, Azotobacter, Klebsiella, Enterobacter, Alcaligenes, Arthobacter, Burkholderia, Bacillus and Serratia have been reported to enhance plant growth (Malfanova et al., 2013).

Biochemically cotton plant is the source of valuable compounds such as terpenes, phenolics, fatty acids, lipids, carbohydrates and proteins. Especially, leaves of cotton plants contain camphene, limonene, myrcene, sabinene and other compounds (Egbuta et al., 2017). Therefore, cotton leaf may harbor endophytes that are potential in plant protection, provide nutrients to the plants, and withstand abiotic stresses. Due to high diversity of soil bacteria and its high contribution to plant growth, traditional microbiological approaches are widely focused on root endophytic bacteria (Compantet al., 2010). On the other hand, leaf endophytic bacteria have not received much attention so far. The present study aims to bridge this gap. Leaf endophytic bacteria are the collection of selective phyllosphere bacteria and they reside in the leaves and maintain endophytic symbiotic relationship with the host plant as well other microbe lives within the leaf. Every microbe within the leaf may have some beneficial function in terms of plant protection as well as to provide nutrients to the plants (Neilands, 1981; Lindowet al., 2003). Studies indicated the predominance of endophytic bacteria in cotton viz., Erwinia sp., Bacillus pumilus, B. brevis, Clavibacter species, Xanthomonas sp (Misaghi and Donndelinger 1990), Agrobacterium sp., Serratia sp., Burkholderia sp., Bacillus sp., Staphylococcus sp., Rhizobium, Variovorax sp., Pseudomonas sp., Acenitobacter sp., Artharobacter sp. And Enterobacter species (McInroy and Kloepper 1995a and b; Mussonet al., 1995). Some endophytes such as Pseudomonas fluorescence 89B-61 found as a controlling agent of Fusarium wilt of cotton caused by Fusarium oxysporum $f$. sp. vasinfectum (Chen et al., 1995). McGee (2002) reported that due to presence of endophytes in leaves, plant is protected from fungal pathogens and pest. For example, methanol extract of endophytes isolated from the cotton leaf reduced the larval growth of insect pest. In another study significant reduction of damping off disease by $R$. solani was observed with the talc-based bioformulation with chitin that containe dendophytic bacteria such as Bacillus EPCO102, Bacillus EPCO16 and Pseudomonas fluorescence Pf1 strains (Rajendran et al., 2008). Therefore, the objective of this study is to isolate bacterial endophytes from cotton leaf and characterize their plant growth promoting traits viz., siderophores production, phosphate solubilization, IAA and ammonia production; and preliminarily screening for chitinase, gelatinase, protease and lipase in order to bioprospect the potential of these endophytic bacteria as biofertilizer or bioprotectant.

\section{Materials and Methods}

\section{Collection of leaf sample and its surface sterilization for isolation of endophytes}

Healthy leaf sample of cotton was collected from the farm at Main Cotton Research Station, Athwa farm, Surat, Gujarat. The collected leaf were taken to the laboratory and preserved at $4^{\circ} \mathrm{C}$ in sealed plastic bags and subjected to isolate endophytic bacteria. 
Surface sterilization of leaf samples was performed according to the method of Musson et al., (1995). Healthy cotton leaf sample was washed by running tap water for 1-2 min followed by 1 min wash with $75 \%$ alcohol to remove the soil particles completely.

Then the leaf sample was washed with sterile $1 \%(\mathrm{v} / \mathrm{v})$ sodium hypochlorite embedded with $0.05 \%(\mathrm{v} / \mathrm{v})$ Triton X-100 for3 min followed by four sequential wash with sterile phosphate buffer ( $\mathrm{pH} 7.0)$. At this point, $0.1 \mathrm{ml}$ of final phosphate buffer washed solution was spread onthe nutrient agar (Musson et al., 1995).

\section{Isolation and preliminary characterization of endophytic bacteria}

After surface sterilization, leaf sample cut into $5 \mathrm{~mm}$ square pieces with sterile blade. Each of the leaf pieces embedded carefully on the surface of different media viz., Nutrient Agar, R2A Agar and Soil Extract Agar (Musson et al., 1995).

Four leaf pieces per plate were placed on each medium. Plating was done in triplicate and all plates were incubated at room temperature $\left(27^{\circ} \mathrm{C}\right)$ for three to four days.

After incubation, suspension of the bacteria which grown surrounding the leaf sample was prepared. Further, isolation and purification of endophytic bacteria was carried out using quadrant method (Sanders, 2012). Each of purified colonies than transferred to nutrient agar slants and were stored at $4^{\circ} \mathrm{C}$.

Bergey's manual of determinative bacteriology was used for recording preliminary cultural characteristics such as size, shape, margin, elevation, consistency, opacity, pigment and gram reaction of isolated bacterial endophytes (MacFaddin, 2000).
Evaluation of plant growth promoting traits of the endophytic isolates

\section{Siderophores detection assay}

Siderophores produced by the endophytic isolates were determined using qualitative and quantitative assay as described by Schwyn and Neilands (1985). For quantitative assay, test isolates were grown in iron free sterile succinic acid medium (Hi-media) for $48 \mathrm{hrs}$ at room temperature at $120 \mathrm{rpm}$. Cell supernatant $(0.5 \mathrm{ml})$ after centrifugation at $15,000 \mathrm{rpm}$ for $5 \mathrm{~min}$ was mixed with $0.5 \mathrm{ml}$ of CAS solution $(1: 1)$ to observe the colour change from blue to orange or yellow. Optimal density was measured at $630 \mathrm{~nm}$ and the percentage of siderophore production was calculated as per formula [(Ar-As $) / \mathrm{Ar}]$ $\times 100=\%$ siderophore units, where $\mathrm{Ar}=$ absorbance of reference (succinic acid media + CAS assay solution), As = absorbance of sample. As a reference sterile succinic acid medium free from inoculates was used. For qualitative analysis, $48 \mathrm{hrs}$ old cultures of endophytic bacteria grown in succinic acid medium were spot inoculated on CAS agar plates and incubated at $27^{\circ} \mathrm{C}$ for $48 \mathrm{hrs}$. Positive reaction was indicated by a color change of the CAS reagent from blue to orange surround the colony shows the siderophores production. Zones index was calculated by dividing yellow/orange zone on CAS agar by growth diameter of spot inoculants (Louden et al., 2011).

\section{Assessment of phosphate solubilization ability}

Quantitative estimation of phosphate solubilization activity of isolates was performed using method described by King (1932). For that, bacterial endophytes inoculated into the sterile Pikovskaya's medium (Pikovskaya, 1948) kept for $48 \mathrm{hrs}$ at room temperature at $120 \mathrm{rpm}$. Culture 
supernatant after centrifugation used to estimate the concentration of soluble phosphate using stannous chloride method (King, 1932). For that, $1.0 \mathrm{ml}$ of the supernatant was mixed with $10 \mathrm{ml}$ of $0.5 \mathrm{M}$ $\mathrm{NaHCO}_{3}, \quad 10 \mathrm{ml}$ of $1.5 \%$ ammonium molybdate, $1 \mathrm{ml}$ of working stannous chloride and the final volume to $50 \mathrm{ml}$ using distilled water. Optimal density measured at $660 \mathrm{~nm}$ after $15 \mathrm{~min}$ of incubation. The concentration of phosphate was estimated using standard curve of tricalcium phosphate in the range of 0.04-0.4 mg/ml.

Qualitative estimation of tricalcium phosphate solubilization was performed using the method of Pikovskaya (1948). Each endophytic cell suspensions were spot inoculated on Pikovskaya's agar plates and incubated at $27 \pm 2^{\circ} \mathrm{C}$ for $48 \mathrm{hrs}$ to observe the zone of solubilisation. Phosphate solubilisation index was calculated by dividing phosphate solubilisation zone on pikovskaya's agar by growth diameter of spot inoculants.

\section{Indole Acetic Acid (IAA) production assay}

The ability of bacterial endophytes to produce IAA was measured using colorimetric method described byLoper and Scroth (1986). For each of endophytic bacterial isolates was grown in sterile nutrient broth embedded with $0.2 \mathrm{ml}$ of $1 \%$ L-tryptophan for $48 \mathrm{hrs}$. Further, $1.0 \mathrm{ml}$ supernatant of each endophytic bacterial isolates mixed with $1.0 \mathrm{ml}$ of Salkowski's reagent to develop the pink colour for the positive result of IAA production and measured at $530 \mathrm{~nm}$. Concentration of IAA produced was estimated against standard curve of IAA in the range of $10-100 \mu \mathrm{g} / \mathrm{ml}$.

\section{Production of ammonia}

The ability of endophytic bacterial strains to produce ammonia was assessed as described by Cappuccino and Sherman (1992). In this method, each isolate inoculated into the $5.0 \mathrm{ml}$ of sterile peptone water broth and incubated at room temperature for $48 \mathrm{hrs}$ at $120 \mathrm{rpm}$. After incubation, $1.0 \mathrm{ml}$ of culture supernatant was mixed with $1.0 \mathrm{ml}$ of Nesseler's reagent. Color change from brown to yellow was measured spectrophotometrically at $450 \mathrm{~nm}$. Concentration of ammonia produced was estimated against standard curve of ammonium nitrate in the range of $0.1-1.0$ $\mu \mathrm{g} / \mathrm{ml}$.

Preliminary screening of endophytic bacterial strains for the chitinase, protease, lipase and gelatinaseproduction

Preliminary study of different enzyme production viz., chitinase, protease, lipase and gelatinase was performed using plate agar assay on the principle of zone of solubilization of the substrate. Solubilization index was calculated by dividing the respective substrate solubilisation zone on agar plate by growth diameter of spot inoculants.

Chitinase activity of bacterial isolates was determined by using chitin agar plates according to the method described by Kuddus and Ahmad (2013). Each bacterial isolate was spot inoculated and incubated for several days at $27 \pm 2{ }^{\circ} \mathrm{C}$ to study the zone of solubilisation.

Protease activity was performed using casein agar plate according to the method described by Olajuyigbe and Ajele (2005). Spot inoculation of each bacterial cell suspension was carried out on casein agar plate, kept for $48 \mathrm{hrs}$ at room temperature to observe the zone of solubilization. Determination of lipase activity was performed using tributyrene agar plate according to method of Sirisha et al., (2010). Endophytic cell suspension was spot inoculated on tributyrene agar plates and incubated for 48-72 hrs at 
room temperature for the formation of zone of solubilization.

Presence of gelatinase was confirmed using preparation of gelatin agar plate according method described by Smith and Goodner (1958). Gelatin agar plates which were spot inoculated by each of the strains were flooded by Frazier's reagent to observe the zone of solubilization after $72 \mathrm{hrs}$.

\section{Results and Discussion}

Isolation of Endophytic bacterial strains from the leaf of $G$. hirsutum and their preliminary characteristics

Before isolation, surface sterilization of the plant tissue is a crucial step to ensure the isolation of endophytes. Thus, confirmation of proper surface sterilization of leaf carried out by inoculating last phosphate buffer wash into the nutrient broth and on nutrient agar plate. Absence of any growth after three days incubation indicated the proper surface sterilization of the leaf sample. The series of washes with tap water, $75 \%$ alcohol followed with sequential wash with sodium hypochlorite reduces $90 \%$ surface contaminants from the plant tissues and ensure proper sterilization (Musson et al., 1995).

To get the diversity of endophytic bacteria, it is necessary to provide different nutrient conditions. Thus, the bacterial endophytes were isolated on three different media viz., Nutrient agar, R2A agar and soil extract agar. As nutrient medium is known for all types of microbes, R2A for oligotrophs and soil extract agar provides nutrients same as present within the soil. Figure 1 shows the growth of bacteria surrounding the leaf sample.

Initially a total of 23 colonies were isolated from the leaf of cotton plant. Of the 23 colonies, eight each were observed on Nutrient and R2A medium; and the other seven on soil extract agar. Further, all these colonies when grown on nutrient medium reduced to 19 colonies based on their similar colony characteristics. Basic cultural characteristics and gram reaction of all endophytic bacterial isolates are presented in Table 1. Out of 19 isolates, ten were gram positive and nine were gram negative rods. All the isolates were colourless except EB9 pigmented as fluorescent green; EB14 as fluorescent blue and EB 11 was brown pigmented. Further, all colonies were found to be round shaped with entire margin except EB2 and EB4 were punctiform and irregular in shape, respectively; while, EB4 showed repand margin. All the isolated bacterial endophytes were transparent except EB2 and EB4, they were opaque. The results are further in confirmation with the findings of Arunachalam and Gayathri (2010) who also reported the variation for cultural characterization of endophytic bacteria isolated from Andrographis paniculata.

\section{Plant growth promoting traits of the endophytic bacterial isolates}

Endophytes are known to provide the plant nutrients, plant health benefits along with protection against pest and disease. Therefore use of endophytes as an alternative ecofriendly method for the sustainable environment. Thus, an attempt has been made to study the endophytic bacteria from the leaf of $G$. hirsutum for their ability to produce plant growth promoting traits viz., siderophores, indole acetic acid, ammonia and ability to solubilize phosphate. Besides these, preliminary study of enzyme production viz., chitinase, protease, gelatinase and lipase were carried out because of their role in plant protection. Table 2 summarizes the presence of plant growth promoting traits and enzyme activities of all 19 endophytic bacterial isolates. 
The siderophores play important role in the growth of plants with their ability to supply iron and suppress of plant pathogens. All isolates were studied qualitatively as well as quantitatively for their siderophores production activity. Among 19 isolates, six were confirmed to produce siderophores by color change from blue to orange. Qualitatively six isolates EB11 (92.58\%), EB4 (88.94\%), EB3 (86.02\%), EB5 (85.41\%), EB8 $(84.44 \%)$ and EB9 $(80.26 \%)$ produced higher siderophores as compared to control (55.04\%) within 48hrs (Fig. 2a and 2b). These isolates showed orange color zone in range of $1.0-2.2 \mathrm{~cm}$ of diameter on CAS plate agar assay. Sharma et al.,(2014) reported siderophore production by Pseudomonas sp in the of range $2.0-2.1 \mathrm{~cm}$ of diameter of orange color zone by two isolates i.e. one isolate from apple Ar-3-kul $(2.0 \mathrm{~mm})$ and one from pear i.e. Pn-1-Kul (2.1mm) site. According to Bashan et al., (2005), siderophore produced by the endophytic bacteria have higher affinity for iron than the siderophore produced by the pathogens of plant; thus the former endophytic bacteria scarvenge most of the available iron, and thereby prevent proliferation of pathogens within the plant especially plant pathogens. Also, some plants can bind and release iron from bacterial ironsiderophore complexes and thus use iron for growth (Bashan et al., 2005).

Table.1 Cultural characteristics and gram reaction of the endophytic bacterial strains

\begin{tabular}{|c|c|c|c|c|c|c|c|c|c|}
\hline $\begin{array}{c}\text { Sr. } \\
\text { No } \\
\text {. }\end{array}$ & $\begin{array}{c}\text { Cult } \\
\text { ure } \\
\text { No. } \\
\end{array}$ & Size & Shape & $\begin{array}{c}\text { Marg } \\
\text { in }\end{array}$ & $\begin{array}{l}\text { Elevati } \\
\text { on }\end{array}$ & $\begin{array}{c}\text { Consiste } \\
\text { ncy }\end{array}$ & Opacity & Pigment & $\begin{array}{c}\text { Gram } \\
\text { reaction }\end{array}$ \\
\hline 1 & EB1 & Small & Round & Entire & Flat & Moist & Transparent & Colourless & $\operatorname{Gram}(-)$ \\
\hline 2 & EB2 & $\begin{array}{l}\text { Pinpoi } \\
\text { nt }\end{array}$ & $\begin{array}{l}\text { Punctifor } \\
\mathrm{m}\end{array}$ & Entire & Flat & Viscous & Opaque & Colourless & $\operatorname{Gram}(+)$ \\
\hline 3 & EB3 & Small & Round & Entire & Convex & Viscous & Transparent & Colourless & $\operatorname{Gram}(+)$ \\
\hline 4 & EB4 & Large & Irregular & $\begin{array}{l}\text { Repan } \\
\text { d }\end{array}$ & Flat & Dry & Opaque & Colourless & $\operatorname{Gram}(+)$ \\
\hline 5 & EB5 & Large & Round & Entire & Convex & Moist & Translucent & Colourless & $\operatorname{Gram}(-)$ \\
\hline 6 & EB6 & Large & Round & Entire & Convex & Moist & Transparent & Colourless & $\operatorname{Gram}(+)$ \\
\hline 7 & EB7 & Small & Round & Entire & Flat & Viscous & Transparent & Colourless & $\operatorname{Gram}(-)$ \\
\hline 8 & EB8 & $\begin{array}{l}\text { Pinpoi } \\
\text { nt }\end{array}$ & Round & Entire & Convex & Dewdrop & Transparent & Colourless & $\operatorname{Gram}(+)$ \\
\hline 9 & EB9 & Small & Round & Entire & Convex & Moist & Transparent & $\begin{array}{l}\text { Fluorescen } \\
\text { t blue }\end{array}$ & Gram(-) \\
\hline 10 & EB10 & $\begin{array}{l}\text { Pinpoi } \\
\text { nt }\end{array}$ & Round & Entire & Raised & Moist & Transparent & Colourless & $\operatorname{Gram}(+)$ \\
\hline 11 & EB11 & Small & Round & Entire & Convex & Viscous & Transparent & Brown & Gram(-) \\
\hline 12 & EB12 & Small & Round & Entire & Raised & Moist & Translucent & Colourless & $\operatorname{Gram}(-)$ \\
\hline 13 & EB13 & Small & Round & Entire & Raised & Moist & Translucent & Colourless & $\operatorname{Gram}(-)$ \\
\hline 14 & EB14 & Small & Round & Entire & Convex & Moist & Translucent & $\begin{array}{l}\text { Fluorescen } \\
\text { t green }\end{array}$ & $\operatorname{Gram}(-)$ \\
\hline 15 & EB15 & $\begin{array}{l}\text { Pinpoi } \\
\text { nt }\end{array}$ & $\begin{array}{l}\text { Punctifor } \\
\mathrm{m}\end{array}$ & Entire & Raised & Dry & Transparent & Colourless & Gram(-) \\
\hline 16 & EB16 & Small & Round & Wavy & Flat & Dry & Transparent & Colourless & $\operatorname{Gram}(-)$ \\
\hline 17 & EB17 & Small & Round & Entire & Convex & Moist & Transparent & Colourless & $\operatorname{Gram}(+)$ \\
\hline 18 & EB18 & Larger & Round & Entire & Flat & Dry & Opaque & Colourless & $\operatorname{Gram}(+)$ \\
\hline 19 & EB19 & $\begin{array}{l}\text { Pinpoi } \\
\text { nt }\end{array}$ & Round & Entire & Convex & Moist & Transparent & Colourless & $\operatorname{Gram}(+)$ \\
\hline
\end{tabular}


Table.2 Data on plant growth promoting traits and the enzyme production of all isolated endophytic bacteria from leaf of G. hirsutam

\begin{tabular}{|c|c|c|c|c|c|c|c|c|}
\hline Isolates & $\begin{array}{l}\text { Siderophore } \\
\text { production }\end{array}$ & $\begin{array}{l}\text { Phosphate } \\
\text { Solubilization }\end{array}$ & $\begin{array}{l}\text { IAA } \\
\text { Production }\end{array}$ & $\begin{array}{l}\text { Ammonia } \\
\text { Production }\end{array}$ & $\begin{array}{l}\text { Protease } \\
\text { Production }\end{array}$ & $\begin{array}{l}\text { Lipase } \\
\text { Production }\end{array}$ & $\begin{array}{l}\text { Gelatinase } \\
\text { Production }\end{array}$ & $\begin{array}{l}\text { Chitinase } \\
\text { Production }\end{array}$ \\
\hline EB1 & - & - & + & + & + & + & + & - \\
\hline EB2 & - & - & + & + & - & - & - & - \\
\hline EB3 & + & - & + & + & - & + & - & + \\
\hline EB4 & + & + & + & + & + & + & - & - \\
\hline EB5 & + & - & + & + & - & + & + & + \\
\hline EB6 & - & - & + & + & + & + & - & - \\
\hline EB7 & - & - & + & + & - & + & + & - \\
\hline EB8 & - & - & + & + & - & - & - & - \\
\hline EB9 & + & + & + & + & + & + & + & - \\
\hline EB10 & + & - & + & + & - & + & - & - \\
\hline EB11 & + & + & + & + & + & + & + & - \\
\hline EB12 & - & - & + & + & + & + & + & - \\
\hline EB13 & - & + & + & + & + & + & - & - \\
\hline EB14 & - & + & + & + & + & + & + & - \\
\hline EB15 & - & - & + & + & + & + & + & - \\
\hline EB16 & - & - & + & + & + & + & + & - \\
\hline EB17 & - & + & + & + & - & + & - & - \\
\hline EB18 & - & - & + & + & + & + & + & - \\
\hline EB19 & - & - & + & + & + & + & - & - \\
\hline Total & 06 & 06 & 19 & 19 & 12 & 17 & 10 & 02 \\
\hline
\end{tabular}

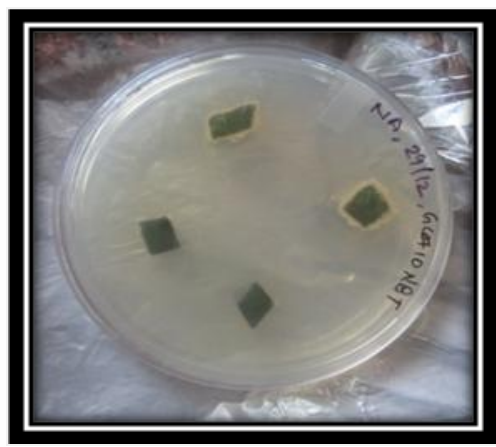

(a)

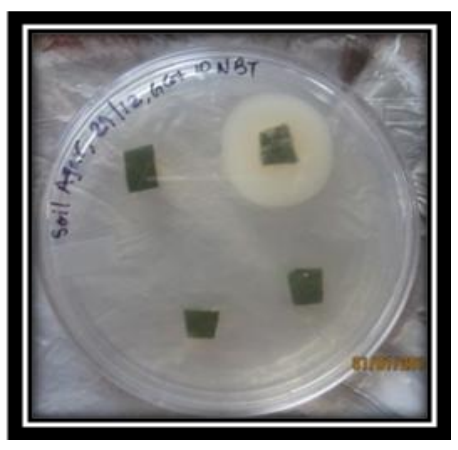

(b)

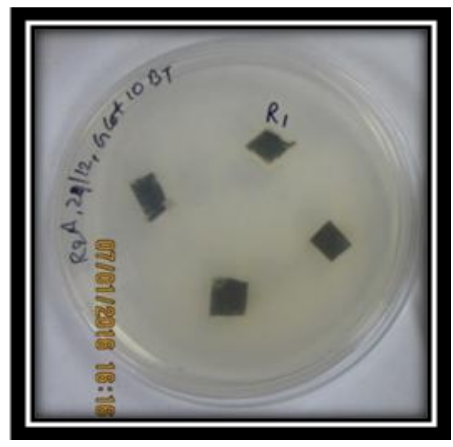

(c)

Fig.1 Growth of endophytic bacteria from leaf sample of G. hirsutum on (a) nutrient agar, (b) Soilextract agar and (c) R2A agar medium 


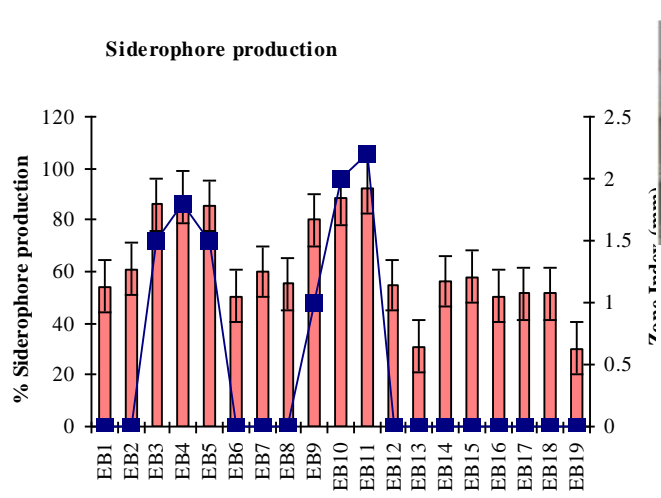

Endophytic bacteria

\section{2(a)}

Fig.2(a) Graphical data represents the qualitative and quantitative production of siderophores by endophytic bacteria

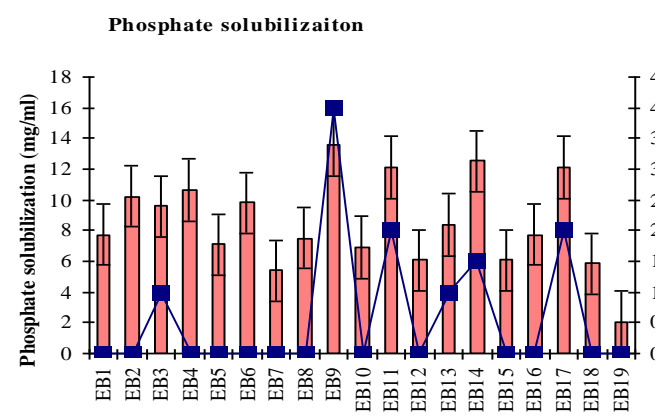

Endophytic bacteria 3(a)

Fig.3(a) Graphical data represents the qualitative and quantitative production of phosphate solubilization by endophytic bacteria

Production of IAA $(\mu \mathrm{g} / \mathrm{ml})$

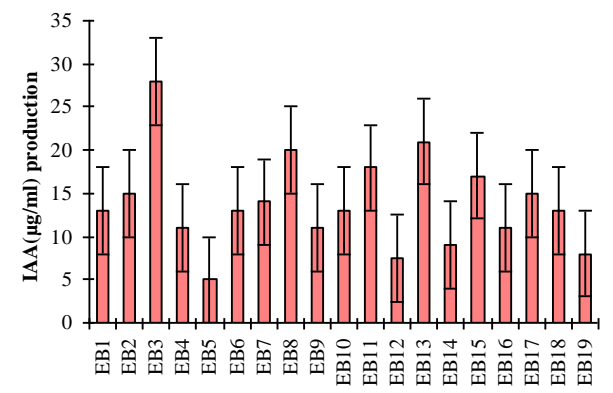

Endophytic bacteria

4(a)

Fig.4(a) Quantitative estimation of $\mathrm{IAA}(\mu \mathrm{g} / \mathrm{ml})$
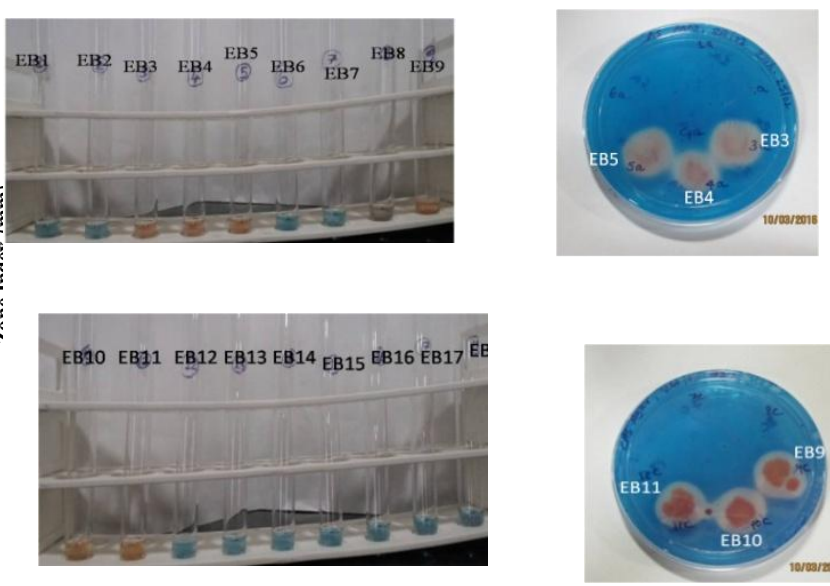

2(b)

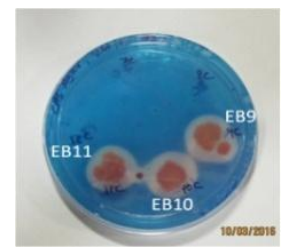

Fig.2(b) Confirmation of siderophores production by color change from blue to orange quantitatively andqualitatively by CAS assay

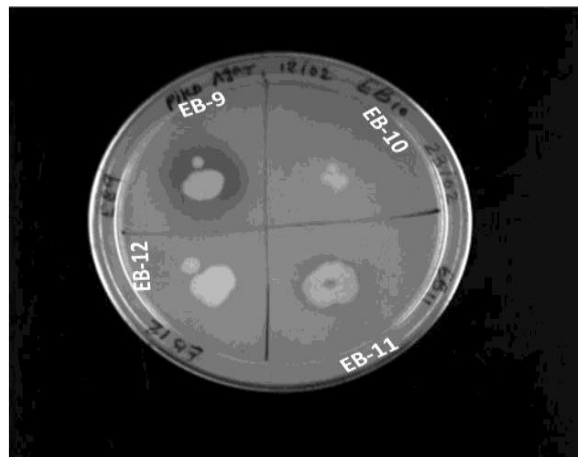

3(b)

Fig.3(b) Solubilization of phosphate on Pikovkya's agar plate by EB9
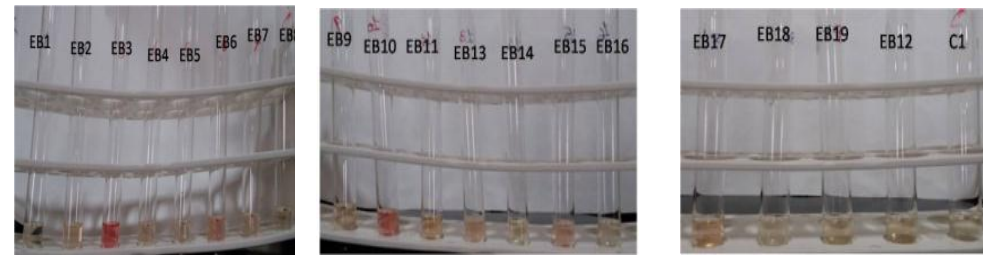

\section{4(b)}

Fig.4(b) Detection of IAA production by development of pink color 


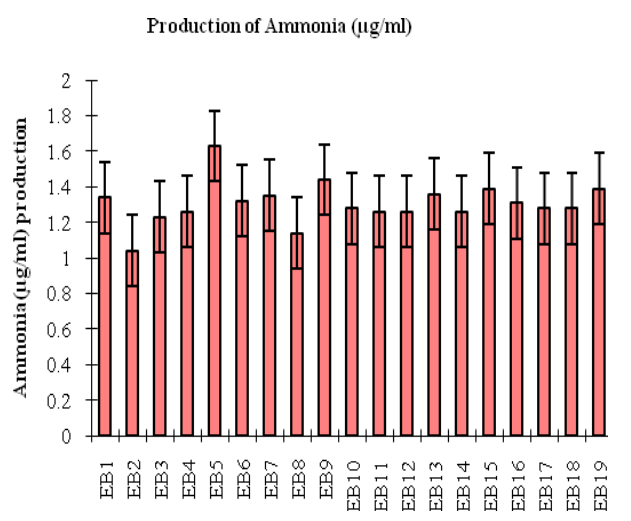

Endophytic bacteria 5(a)

Fig.5(a) Quantitative determination of ammonia production $(\mu \mathrm{g} / \mathrm{ml})$
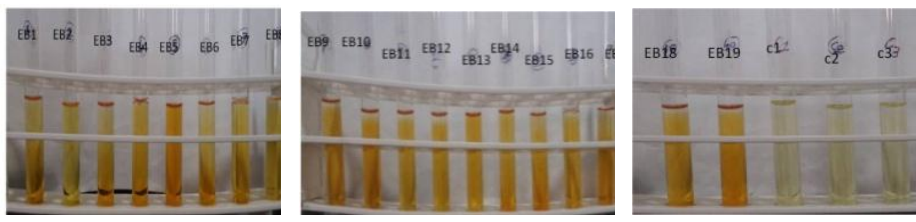

5(b)

Fig.5(b) Color change of yellow to brown due to production of ammonia after addition of Nessler's reagent
Endophytes move into plants from soil through cracks due to emerging lateral root; from roots bacteria spread in leaves, flowers and fruits via vascular plant system (Hardoim et al., 2008; Compant et al., 2011). Thus, endophytes from leaf may have possible mechanism of phosphate solubilization. Assessment of phosphate solubilization in the present work indicated that only one strain EB9 had shown significant phosphate solubilization both qualitatively $(4.0 \mathrm{~mm})$ and quantitatively $(13.58 \mathrm{mg} / \mathrm{ml})$. Zones of solublization data were not exactly matched with the activity of solubilization with liquid assay within the duration of $48 \mathrm{hrs}$. The strains EB11 (12.12mg/ml), EB14 $(12.54 \mathrm{mg} / \mathrm{ml}), \quad$ EB17 $(12.12 \mathrm{mg} / \mathrm{ml}), \quad$ EB4 $(10.65 \mathrm{mg} / \mathrm{ml})$ and EB2 $(10.24 \mathrm{mg} / \mathrm{ml})$, which showed significant solubilization of tricalcium phosphate by stannous chloride method did shows less significant or no zone with agar plate assay. Data are presented in Figures $3 \mathrm{a}$ and $3 \mathrm{~b}$ and that represents the solubilization of phosphate by EB9 strain on Pikovskaya's medium. According to Johnston (1952), it might be due to the different strategies used by bacteria to solubilize phosphate, the time duration, type and amount of organic acid produced by diversified bacterial strain etc. Detailed study will be required to know the factors behind the differences of results using agar and liquid assay.

Indole acetic acid production by bacteria is a part of mechanism between plant-microbial interactions. IAA is an auxin that regulates the plant growth and its cell division. To determine the IAA production each isolate was grown in nutrient medium embedded with tryptophan because tryptophan is believed to be the primary precursor for the formation of IAA in microbes (Monteiro et al., 1988). After $72 \mathrm{hrs}$ incubation, addition of Salkowski's reagent showed significant amount of IAA production with the bacterial endophytes EB3 (28 $\mu \mathrm{g} / \mathrm{ml}), \quad$ EB13 (21 $\mu \mathrm{g} / \mathrm{ml})$, EB8 $(20 \mu \mathrm{g} / \mathrm{ml})$, EB11 $(18 \mu \mathrm{g} / \mathrm{ml})$, EB15 $(17 \mu \mathrm{g} / \mathrm{ml}), \mathrm{EB} 2$ and EB17 $(15 \mu \mathrm{g} / \mathrm{ml})$. Other strains also produced IAA in small or negligible amount (Fig. 4a and 4b). Sharma et $a l$. , (2015) reported IAA production on luriabertani broth by Bacillus spp. ranging from 12 to $25 \mu \mathrm{g} / \mathrm{ml}$.

Ammonia production is an important plant growth promoting trait, where microbes can able to breakdown complex nitrogenous materials and convert it into ammonia, which is taken up by plant as a nitrogen source. 
Also, formation of ammonia leads to alkaline condition, which suppresses the growth of certain pathogenic fungi (Jha et al., 2012). In our study, peptone was used as a nitrogenous compound which breakdown leads to formation of ammonia; it was detected by color change using Nessler's reagent. In the present study, it was observed that all endophytic isolates showed ammonia production in the range of $1.6-0.8(\mu \mathrm{g} / \mathrm{ml})$ within 48 hrs (Fig. 5a and 5b). Significant differences were not recorded for ammonia production among all 19 isolates.

\section{Preliminary assessment of enzymes production of endophytic bacteria}

On leaves of plant, limited sites are available where the pathogen can attack the plant. Bacteria capable of multiplying within the leaf can compete with pathogens by producing enzymes or such chemical compounds as a metabolic product. Diverse group of microbes as an endophytes lives within the plant tissues. From that, such microbes are able to synthesize and secret hydrolytic enzymes. Many microbes produce and excrete lytic enzymes such as chitinase, protease, gelatinase and lipase, which can hydrolysepolymeric compounds viz., chitin, proteins and lipids. Secretion of these enzymes by different microbes results in the suppression of plant pathogenic activity directly (Pal et al., 2006). For example, fungal cell wall made up of chitin, which might be breakdown by endophytic microbial chitinase (Bashan et al., 2005). Plate agar assay was used for the preliminary study of enzyme production by the isolates. Among 19 isolates, two bacterial strains EB5 $(1.9 \mathrm{~mm})$ and EB3 $(1.1 \mathrm{~mm})$ showed zone of solubilization with chitin agar plate after 7 days. Protease production was shown by six isolates, EB15 (16.60mm), EB12 (14.00mm), EB11 $(13.60 \mathrm{~mm})$, EB1 $(12.60 \mathrm{~mm})$ and EB4 $(11.80 \mathrm{~mm})$. Gelatinase activity was recorded in five strains EB1 $(17.00 \mathrm{~mm}), \quad \mathrm{EB} 9$ (12.50mm), EB11 (15.50mm), EB12 (10.00) and EB16 $(15.70 \mathrm{~mm})$ on gelatin agar plate. Significant lipase activity on tributyrene agar plate was recorded with EB10 (15.00mm), EB13 (13.70mm), EB17 (12.80mm) EB14 $(12.20 \mathrm{~mm}), \mathrm{EB} 12 \quad(11 \mathrm{~mm})$ and EB11 (10mm). Rajendran (2006) reported that application of endophytes such as Bacillus species and Pseudomonas species to cotton plant induced the expression of chitinase and other enzymes which reduced the disease severity caused by Xanthomonas axonopodis pv. malvacearum. Similarly, Khianngam et al., (2013) isolated and screened twenty endophytic bacteria from mangrove plants in Thailand for the presence of hydrolytic enzymes viz., proteases, lipases, amylases or cellulases.

From our study, it can be concluded that all the 19 endophytic bacterial strains studied are potential strains for the one or other plant growth promoting traits and hydrolytic enzymes involved in protection against pest and disease. These potential isolates could be used to make consortium as biofertilizer or bioprotectant to enhance plant productivity and protection. Among 19 isolates, EB9 and EB11 showed all activities except chitinase production, thus these two are the candidates endophytic bacterial strains to be studied at molecular level along with their effects on plant growth under pot and field conditions that would help us to understand the plant microbe interaction in detail.

\section{References}

Arunachalam, C., and Gayathri, P. 2010.Studies on bioprospecting of endophytic bacteria from the medicinal plant of Andrographis paniculata for their antimicrobial activity and antibiotic susceptibility pattern. Int. J. Cur. Pharm. Res. 2(4): 63-68. 
Bakker, A. W., and Schippers, B. 1987. Microbial cyanide production in the rhizosphere in relation to potato yield reduction and Pseudomonas spp. mediated plant growth-stimulation. Soil Biol. Biochem. 19(4):451-457.

Bashan, Y., and De Bashan, L. E. 2005. Plant growth promotingIn encyclopedia of soils in the environment edited by: D. Hillel. American Society of Microbiology: Washington DC. pp. 607654.

Bhattacharyya, P. N., and Jha, D. K. 2012. Plant growth-promoting rhizobacteria (PGPR): emergence in agriculture. World J. Microbiol. Biotechol. 28(4): 1327-1350.

Cappuccino, J. C., and Sherman, N. 1992. In: Microbiology: A Laboratory Manual. Edited by:: Benjamin/cummings. Pub.Co. New York. pp. 125-179.

Chen, C., Bauske, E. M., Musson, G., Rodriguezkabana, R. and Kloepper, J. W. 1995.Biological control of Fusarium wilt on cotton by use of endophytic bacteria. Biol. Control. 5(1): 83-91.

Compant, S., Clément, C. and Sessitsch, A. 2010.Plant growth-promoting bacteria in the rhizo-and endosphere of plants: their role, colonization, mechanisms involved and prospects for utilization. Soil Biol. Biochem. 42(5): 669-678.

Compant, S., Mitter, B., Colli-Mull, J. G., Gangl, H. and Sessitsch, A. 2011.Endophytes of grapevine flowers, berries, and seeds: identification of cultivable bacteria, comparison with other plant parts, and visualization of niches of colonization. Microb. Ecol. 62(1): 188-197.

Defago, G., and Haas, D. 1990. Pseudomonads as antagonists of soilborne plant pathogens: modes of action and genetic analysis. In Soil biochemistry Edited by: J.M. Bollag and G. Stotzky. Marcel Dekker, Inc., New York. pp. 249-291.

Egbuta, M.A., McIntosh, S., Waters, D.L., Vancov, T. and Liu, L. 2017.Biological importance of cotton by-products relative to chemical constituents of the cotton plant. Molecules. 22(1): 93.

Hallmann, J., Quadt-Hallmann, A., Rodrıguez-Kábana, R. and Kloepper, J.W. 1998.Interactions between Meloidogyne incognita and endophytic bacteria in cotton and cucumber. Soil Biol. Biochem. 30(7): 925-937.

Hardoim, P. R., van Overbeek, L. S. and van Elsas, J. D. 2008. Properties of bacterial endophytes and their proposed role in plant growth. Trends Microbiol. 16(10): 463-471.

Jha, C. K., Patel, B. and Saraf, M. 2012.Stimulation of the growth of Jatropha curcas by the plant growth promoting bacterium Enterobacter cancerogenus MSA2. World J. Microbiol. Biotechnol. 28(3): 891-899.

Johnston, H.W., 1952. The solubilization of phosphate: The action of various organic compounds on dicalcium and tricalcium phosphates. N. Z. J. Sci. Technol. 436-446.

Kachhap, S., Chaudhary, A. and Singh, S. D. 2015. Response of plant growth promoting rhizobacteria (pgpr) in relation to elevated temperature conditions in groundnut (Arachis hypogaea L.). The Ecoscan. 9(3and4): 771-778.

Khianngam, S., Techakriengkrai, T., Raksasiri, B.V., Kanjanamaneesathian, M. and Tanasupawat, S. 2013. Isolation and screening of endophytic bacteria for hydrolytic enzymes from plant in mangrove forest at Pranbur i, PrachuapKhiri Khan, Thailand. In Endophytes for plant protection: the state of the art Edited by: Schneider C, Leifert C, Feldmann F. Proc 5th 
IntSymp Plant Protect Plant Health Europe. Deutsche Phytomedizinische Gesellschaft, Berlin.pp 279-284.

King, E. J., 1932.The colorimetric determination of phosphorus. Biochem. J. 26(2): 292.

Kirti, S., Dipta, B., Bhardwaj, S., Pawar, R. and Kaushal, R. 2016. Screening and characterization of plant growth promoting rhizobacteria associated with cherry

(Prunusavium

L.). Screening. 11(4): 2111-2115.

Kuddus, M., and Ahmad, I.Z. 2013.Isolation of novel chitinolytic bacteria and production optimization of extracellular chitinase. J. Genetic Eng. Biotechnol. 11(1): 39-46.

Lindow, S. E., and Brandl, M. T. 2003.Microbiology of the phyllosphere. Appl. Environ. Microbiol. 69(4): 1875-1883.

Loper, J.E., and Schroth, M.N., 1986. Influence of bacterial sources of indole3 -acetic acid on root elongation of sugar beet. Phytopathology. 76(4): 386-389.

Louden, B.C., Haarmann, D. and Lynne, A. M. 2011.Use of blue agar CAS assay for siderophore detection. J. Microbiol. Biol. Edu. 12(1): 51.

MacFaddin, J. F., 2000. Biochemical tests for identification of medical bacteria. Williams and Wilkins, London.

Malfanova, N., Kamilova, F., Validov, S., Chebotar, V. and Lugtenberg, B. 2013.Is L-arabinose important for the endophytic lifestyle of Pseudomonas. Arch. Microbiol. 195: 9-17.

McGee, P.A., 2002. Reduced growth and deterrence from feeding of the insect pest Helicoverpa armigera associated with fungal endophytes from cotton. Anim. Prod. Sci.42 (7): 995-999.

McInroy, J. A., and Kloepper, J. W. 1995a. Population dynamics of endophytic bacteria in field-grown sweet corn and cotton. Can. J. Microbiol.41: 895-901.
McInroy, J.A., and Kloepper, J. W. 1995b.Survey of indigenous bacterial endophytes from cotton and sweet corn. Plant Soil, 173: 337-342.

Misaghi, I. J., and Donndelinger, C.R. 1990.Endophytic bacteria in symptomfree cotton plants. Phytopathology. 80(9): 808-811.

Monteiro, A.M., Crozier, A. and Sandberg, G. 1988.Endogenous hormones, germination and early seedling growth of Dalbergia dolicbopetala.J. Pl. Physiol. 132(6): 762-765.

Musson, G., McInroy, J. A. and Kloepper, J. W. 1995.Development of delivery systems for introducing endophytic bacteria into cotton. Biocontrol Sci. Technol. 5(4): 407-416.

Neilands, J. B., 1981. Iron absorption and transport in microorganisms. Annu. Rev. nutr. 1(1): 27-46.

Olajuyigbe, F.M. and Ajele, J.O. 2005. Production dynamics of extracellular protease from Bacillus species. Afr. J. Biotechnol. 4(8): 776.

Pal, K. K., and Gardener, B. M. 2006.Biological control of plant pathogens. The Plant Health Instructor. 2: 1117-1142.

Pikovskaya, R. I., 1948. Mobilization of phosphorus in soil in connection with vital activity of some microbial species. Mikrobiologiya. 17(362): 370.

Rajendran, L., Saravanakumar, D., Raguchander, T.G. and Samiyappan, R. 2006. Endophytic bacterial induction of defence enzymes against bacterial blight of cotton. Phytopathol.Mediterr.45 (3): 203-214.

Rajendran, S., and Sriranjini, V. 2008.Plant products as fumigants for storedproduct insect control. J. Stored Prod. Res. 44(2): 126-135.

Sanders, E.R., 2012. Aseptic laboratory techniques: plating methods. J. Vis. Exp. (63): e3064. 
Schwyn, B., and Neilands, J. B. 1987.Universal chemical assay for the detection and determination of siderophores. Analytical Biochem. 160:47-56.

Sharma, R., Walia, A., Chauhan, A. and Shirkot, C. K. 2015.Multitrait plant growth promoting bacteria from tomato rhizosphere and evaluation of their potential as bioinoculants. App. Biol. Res.17: 1-12.

Sharma, S., Kaur, M. and Prashad, D. 2014.Isolation of fluorescent Pseudomonas strain from temperate zone of himachalpradesh and their evaluation as plant growth promoting rhizobacteria (PGPR). The Bioscan. 9(1): 323-328.

Sirisha, E., Rajasekar, N. and Narasu, M. L. 2010. Isolation and optimization of lipase producing bacteria from oil contaminated soils. Adv. Biol. Res. 4(5): 249-252.

Smith Jr, H.L., and Goodner, K. 1958. Detection of bacterial gelatinases by gelatin-agar plate methods. $J$. Bacteriol. 76(6): 662.

\section{How to cite this article:}

Azba A. Shaikh, P.R. Parmar, B.K. Rajkumar, D.H. Patel, H.R. Desai and Solanki B.G. 2017. Bioprospecting Potential of Endophytic Bacteria from Leaves of Gossypium hirsutum. Int.J.Curr.Microbiol.App.Sci. 6(10): 1718-1730. doi: https://doi.org/10.20546/ijcmas.2017.610.208 